Historic, Archive Document

Do not assume content reflects current scientific knowledge, policies, or practices. 

Rocky

Mountains

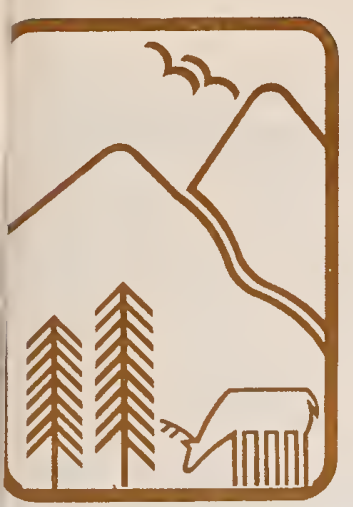

Southwest

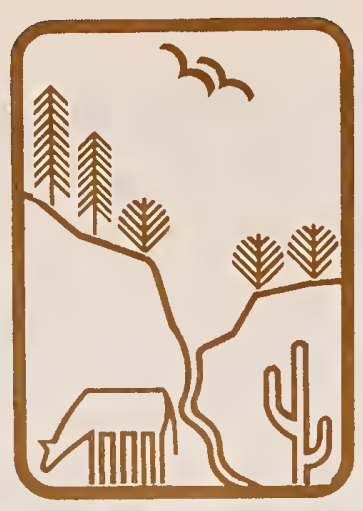

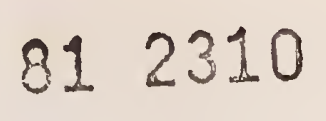

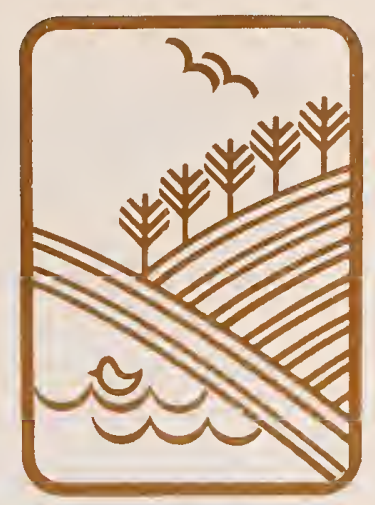

May 1981

\title{
Preliminary Burning Prescriptions for Ponderosa Pine Fuel Reductions in Southeastern Arizona
}

\author{
Michael G. Harrington'
}

\begin{abstract}
Natural ponderosa pine fuels can be safely burned with air temperatures between $55^{\circ}$ and $75^{\circ} \mathrm{F}$, relative humidities between $25 \%$ and $50 \%$, and windspeeds less than 10 miles per hour. The moisture content of the surface $\mathrm{L}$ layer needles should be between $5 \%$ and $10 \%$. Total fuel reduction will depend on $\mathrm{H}$ layer moisture. Burning under these conditions will lessen the wildfire hazard by reducing fuel loadings, thinning the stand, removing ladder fuels, and raising the canopy level.
\end{abstract}

Keywords: Fuel reduction, hazard reduction, burning prescription, Pinus ponderosa var. arizonica.

\section{Management Implications}

The primary purpose of prescribed burning under natural stand conditions, in the ponderosa pine (Pinus ponderosa var. arizonica) zone of the Santa Catalina Mountains, is to reduce the fire hazard caused by 70 years of fuel buildup, and by high lightning and human. caused ignition risks. Because damp, cool fall weather often leads to inadequate burning treatments, summer burning was attempted as an alternative. Light, surface fuels were effectively consumed by fire within a few days after heavy rainshowers. This reduced the ignitability and rate of spread potential, at least temporarily. Canopy, ladder, and additional ground fuels were reduced by burning near the drier prescription limits. These reductions further decreased potential fire intensity, total energy release, and unfavorable fire effects.

Prescribed burning reduced heavy fuels to varying degrees. Fuel groups were affected more than single fuel pieces. In general, under similar conditions, most heavy woody material will be at least charred, if not greatly reduced, making it less ignitable.

'Research Forester, Rocky Mountain Forest and Range Experiment Station, Research Work Unit in Tempe, in cooperation with Arizona State University. Headquarters is in Fort Collins in cooperation with Colorado State University.
Few control problems were encountered while burning during the summer. However, during these initial fuel reduction burns, backing fires are essential for control and reduction of damage.

\section{Introduction}

Heavy recreation use in the Santa Catalina Mountains in southeastern Arizona has considerably increased the risk of human-caused fires. In the ponderosa pine and Douglas-fir (Pseudotsuga menziesii) zones, above 6,000 feet, the number of human-caused fires has increased three-fold from the 1960's to the 1970's. ${ }^{2}$ These forest zones also experience a high incidence of lightning fires with a yearly average of one fire for every 1,200 acres. ${ }^{2}$ Because of effective fire suppression, many of the ponderosa pine stands in these mountains have been untouched by large-scale fires for 65.75 years, ${ }^{3}$ leading to the accumulation of abundant natural fuels. Steep slopes and overstocked groups of pine saplings add to the risk, creating a potentially dangerous fire situation. The potential damage of wildfire is increased because of radar equipment and numerous mountain home devel. opments within these hazard zones. All these factors suggest a need for fuel reduction measures.

${ }^{2}$ Data on file, Santa Catalina Ranger Station, Tucson, Ariz.

${ }^{3}$ Data on file, Fuel Management Project, RM-2108, Tempe, Ariz. 
In southwestern ponderosa pine forests, most prescribed burns are conducted in the fall for safety and better predictability. In the fall, after fuels have been dampened and temperatures and humidities have moderated, fires burn with less intensity and are generally less hazardous than during the warmer, drier summer.

Occasionally, the weather and fuels remain too dry into the autumn, to permit favorable, prescribed burning. Conversely, summers are often followed by damp, cool fall weather which can minimize the effectiveness of prescribed fires, or prevent fire treatments entirely. If weather conditions postpone fuel reduction programs, having another season to conduct prescribed fires may be helpful.

July and August are a potentially good prescribed burning period. In Arizona, late spring is normally hot and dry, with little rain. In midsummer, moist air moves north into this region, causing frequent thunderstorms. Fuels are again dampened, relieving the extreme fire danger and possibly permitting burning.

The primary purpose of this study was to begin to develop midsummer burning prescriptions for ponderosa pine stands in southeastern Arizona. Fuel moisture contents were studied closely to determine their effects on fuel reduction by burning.

\section{Study Area}

The study area was on southwest facing, $30.50 \%$ slopes, in the Santa Catalina Mountains, 10 miles northeast of Tucson, Ariz. At this 8,000 foot elevation, annual precipitation averages 30 inches. About $10 \%$ of this precipitation falls in spring, with the other $90 \%$ equally distributed throughout summer, fall, and winter. The forests are composed primarily of uneven-aged stands with even-aged groups (fig. 1), typical of much of Arizona's ponderosa pine. The stand is predominantly 5 -needle ponderosa pine, with a mixture of Douglas-fir, southwestern white pine (Pinus strobiformis), and silver

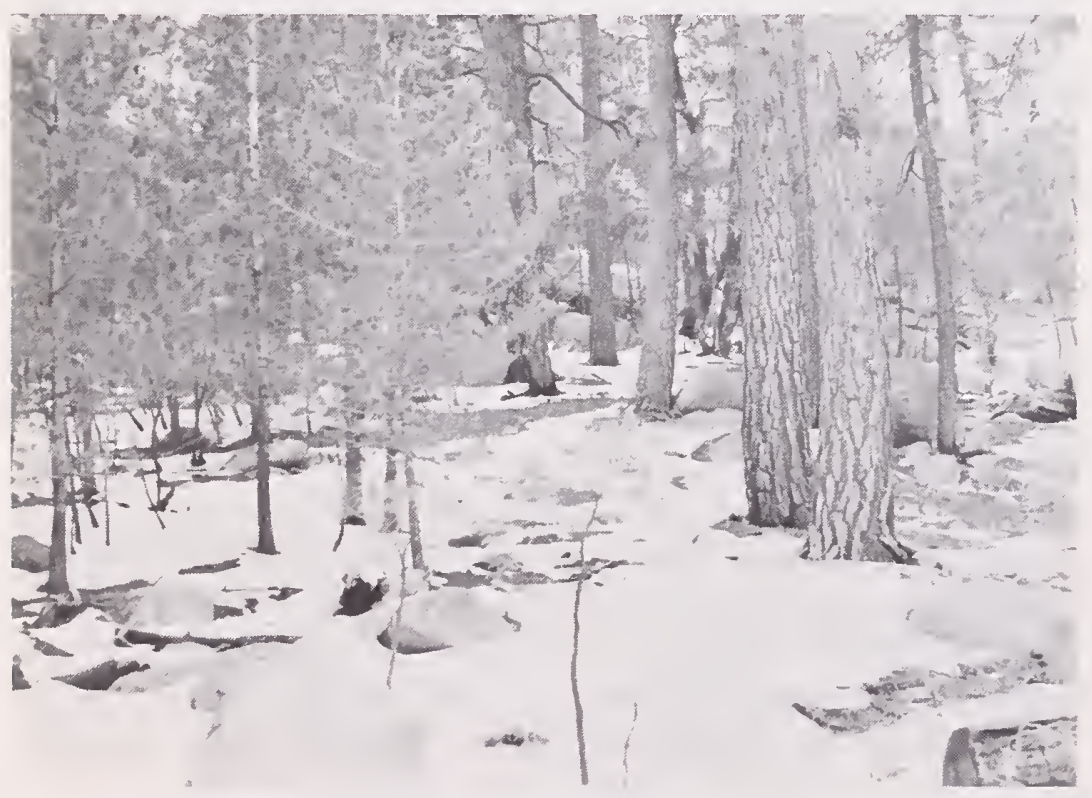

Figure 1.-Ponderosa pine stand with two maturity groups, open group on the right and closed group on the left. leaf oak (Quercus hypoleucoides). The forest floor fuels are mostly needles, with naturally fallen woody material, including scattered, downed logs.

\section{Methods}

The study site was divided into three areas, about 3 acres each. Six plots were established within each of the areas. Because the stand consisted of two distinct maturity groups (fig. 1), three plots were located in each group, in each area. The open groups were characterized by large, old growth ponderosa pine, and the closed groups, commonly called "dog-hair thickets," consisted of dense, overstocked clumps of ponderosa saplings. Criteria for plot location were homogeneity and good representation of both stand and fuels.

Each plot consisted of a non-random 3 by 3 grid, with each of the nine points being sample points spaced 20-25 feet apart, depending on group sizes. To estimate the forest floor needle and woody fuel components smaller than 1 inch in diameter, a 1 -square-foot sample from each of the nine sample points was cut to mineral soil, bagged, and returned to the lab for oven-dry weight determination. Four of the nine collections were separated into three distinct stages of forest floor decom. position. The L layer (litter) is the newly fallen, surface fuel. The $\mathrm{F}$ layer (fermentation) consists of material in the early stages of decomposition and weathering. $\mathrm{H}$ layer (humus) fuels are in the advanced stages of decomposition, immediately above mineral soil, where separate fuel components are difficult to distinquish. The weights of specific components of each layer (needles, 0 - to 0.25 -inch twigs, 0.25 - to 1 -inch twigs, oak leaves, bark, and cone parts) were determined. Sackett's (1979) collection and laboratcry methods were followed. Four forest floor depth measurements were taken for each square foot of material removed.

Downed, woody fuel with diameters between 1 and 3 inches was sampled along three transects running across the plot between the sample points. Intercepts of fuels in this size class were counted, and a weight per area was determined using Brown's (1974) method.

The length and mid-diameters of all woody fuel pieces greater than 3 inches in diameter were measured within a 0.05 -acre circular sample. Only that portion of fuel pieces which fell within the 0.05 acre was measured. Fuel volumes were computed using length and diameter measurements, and weights were determined using accepted densities of either sound or rotten woody material sampled.

To estimate stand characteristics in each plot, the diameter at breast height and species of each tree occurring within a 0.067-acre circular sample were recorded.

A weather station equipped with a recording rain gage and hygrothermograph was set up adjacent to area 1. Fuel moisture stick values, in addition to temperature, precipitation, and relative humidity, were also measured at a permanent fire weather station, Palisades, a few hundred yards from the study site. 
Fuel was sampled to determine moisture content during the burning. Six samples each of $\mathrm{L}$ layer needles, $\mathrm{F}$ layer needles, and $\mathrm{H}$ layer humus were collected from each maturity group. Each sample consisted of a composite of four or five subsamples. Also, woody material from two sound and two rotten logs were collected from the closed and open groups, immediately before burning. The upper 5 inches of the log were sampled with separations made for the surface 1 inch, $1-3$ inches, and 3-5 inches. Moisture contents were determined gravimetrically.

Figure 2 shows the relationship of July and August precipitation to the three burning dates. A 15-day rainless period ended on July 17 , beginning 5 rainy days. Area 1 was burned on July 24, 3 days after these rains. Four days after two brief rains, the second area was ignited (August 3). Finally, area 3 was burned 4 days after a 2-week period of rain. Backing fires were used almost exclusively, with the exception of one series of short strip head fires required at the end of one day.

During burning, flame lengths were estimated, and rates of fire spread were measured periodically. Fireline intensities were estimated using the inverse of the formula, Flame Length $=0.45$ (Intensityo.46) (Byram 1959). After the burning, fuels were collected near established points, using the same sampling scheme as in the preburn sampling. The distances that the lower portion of the crowns were raised were visually estimated after the scorched needles had fallen.

\section{Analysis}

Fuel moisture contents for the three areas within maturity groups were statistically compared using analyses of variance and linear contrasts. This method also was used to compare the reduction of forest floor material $\leqslant \mathbb{1}$ inch in diameter, needle fuels, and total fuels, resulting from the three fires. Too much variation between plots because of light sampling intensity, made it impossible to statistically compare reduction of other fuels.

\section{Results and Discussion}

\section{Stand and Fuel Description}

Because of differences in tree sizes and spacings between the open and closed groups (fig. 1), data from the two maturity groups were evaluated separately. Group characteristics were as follows:

Average d.b.h. (inches)

Open Closed
groups groups

Density (trees per acre)

5.2

603

Basal area (square feet per acre)
2.5

3,512

186

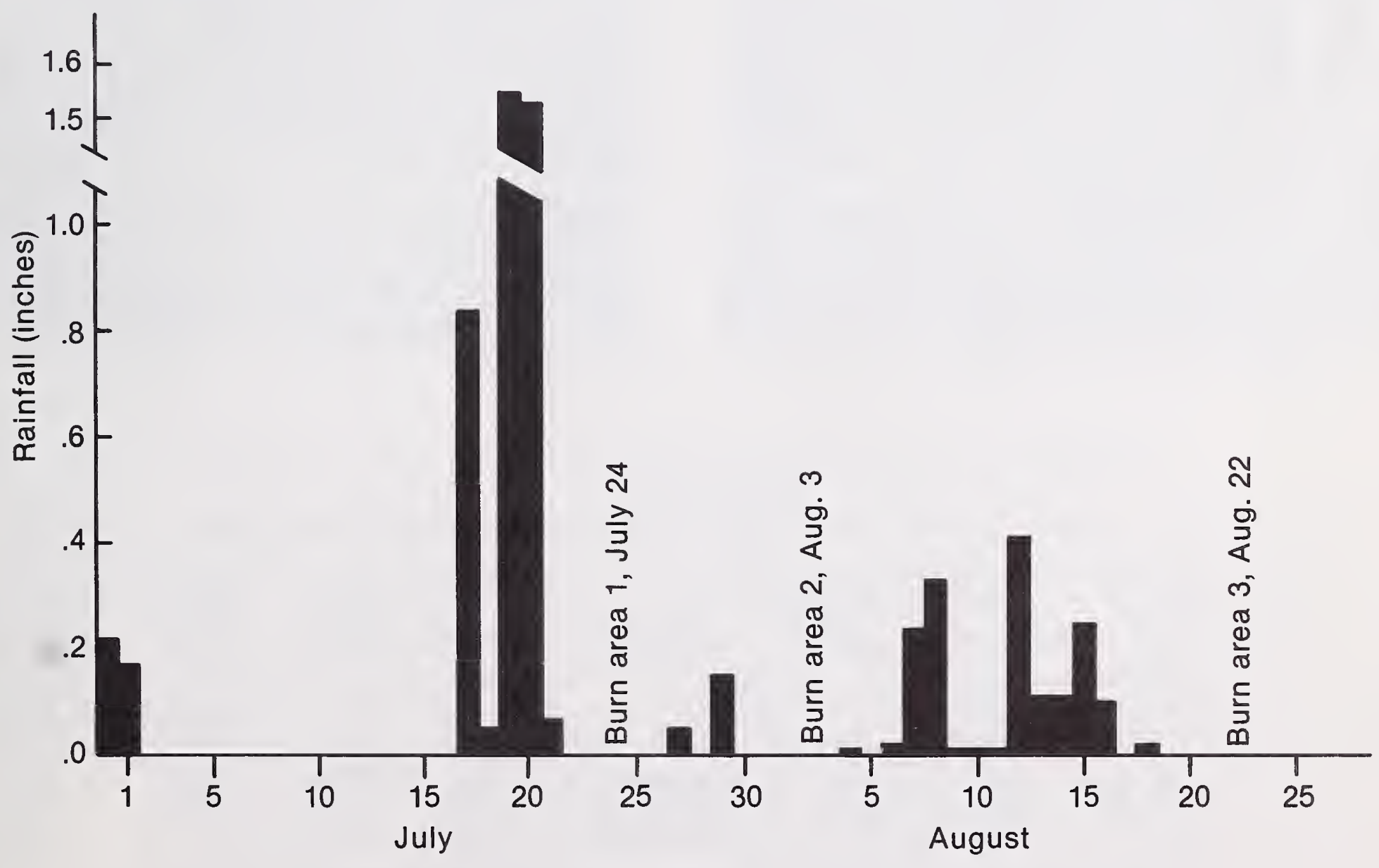

Figure 2.-Three prescribed burns in relation to July and August precipitation. 
Ponderosa pine is the obvious dominant in both maturity groups. In the open and closed groups, ponderosa pine makes up $65 \%$ and $87 \%$ of the trees per acre, respectively, and $91 \%$ and $79 \%$ of the basal area, respectively. Southwestern white pine, which appears to be increasing because of the absence of fire, is next in number of trees per acre, but the trees are relatively small. The closed groups have more and larger oaks as well as a few Douglas-firs.

Fuel weights in each maturity group were as follows:

\section{Open Closed groups groups}

Needles/humus

0 - to 0.25 -inch twigs

0.25 - to 1 -inch twigs

Miscellaneous

$\leqslant 1$-inch material (forest floor)

1. to 3 -inch woody material

$>3$-inch woody material (sound)

$>3$-inch woody material (rotten)

Total fuel loading
-. tons per acre --

\begin{tabular}{rr}
24.2 & 19.9 \\
0.3 & 0.4 \\
1.0 & 1.0 \\
3.2 & 2.1 \\
\hline
\end{tabular}

$28.7 \quad 23.4$

$0.7 \quad 0.9$

$1.0 \quad 4.0$

$3.1 \quad 6.0$

$33.5 \quad 34.3$

\section{Burning Conditions and Fire Behavior}

The weather conditions and fire behavior observations for the three burns are shown in table 1.

Weather and fire behavior differences among the three burns were slight, except for relative humidities. Flame lengths and calculated fireline intensities were somewhat greater in area 3 than area 2 . Area 1 fires had the lowest intensities. These intensity differences likely resulted from fuel moisture differences (table 2).

Area 1 was subjected to the greatest amount of rain and least number of effective drying days before burning, and, in general, had much wetter fuels. Area 2 had little rainfall immediately preceding burning, and the drying days were sufficient to reduce moisture in most fuels to
Table 2.-Average fuel moistures (in percent) and standard deviations during three prescribed burns ( $n=6$ samples)

\begin{tabular}{lclll}
\hline $\begin{array}{c}\text { Maturity } \\
\text { group }\end{array}$ & Area & L.needles & F.needles & H.humus \\
& & & & \\
\hline Open & 1 & $6.4 \pm 1.8 \mathrm{a}^{1}$ & $23.1 \pm 11.2 \mathrm{a}$ & $88.4 \pm 34.1 \mathrm{a}$ \\
& 2 & $6.0 \pm 0.8 \mathrm{a}$ & $6.8 \pm 1.6 \mathrm{~b}$ & $21.4 \pm 5.0 \mathrm{~b}$ \\
& 3 & $4.7 \pm 1.3 \mathrm{a}$ & $8.6 \pm 3.3 \mathrm{~b}$ & $32.4 \pm 10.7 \mathrm{~b}$ \\
& & & & \\
Closed & 1 & $9.2 \pm 1.5 \mathrm{a}$ & $64.1 \pm 16.5 \mathrm{a}$ & $79.0 \pm 28.9 \mathrm{a}$ \\
& 2 & $7.6 \pm 1.6 \mathrm{a}, \mathrm{b}$ & $10.7 \pm 0.9 \mathrm{~b}$ & $30.3 \pm 18.2 \mathrm{~b}$ \\
& 3 & $6.0 \pm 1.1 \mathrm{~b}$ & $14.5 \pm 7.4 \mathrm{~b}$ & $53.0 \pm 26.0 \mathrm{a}, \mathrm{b}$
\end{tabular}

\footnotetext{
${ }^{1}$ Means in columns within each maturity group followed by different letters are significantly different, $P=0.05$.
}

the lowest of three areas. Area 3 fuels were influenced by a prolonged rainy period, but two extremely dry days, with steep vapor pressure gradients, just prior to burning, dried the light surface fuels to the lowest moisture content of the three areas, and dried other fuels to a lesser degree.

\section{Fuel Reduction}

Table 3 shows weight and depth reductions of forest floor fuels from the three burns. Forest floor weight reductions reflect needle weight reductions because needles and humus make up at least $80 \%$ of the forest floor. In both groups, areas 2 and 3 fuel weight and depth reductions were statistically similar, in most cases, but both were significantly greater than reductions on area 1. This coincides with $F$ and $H$ layer moisture differences (table 2). A noted exception occurred in the open group, where total fuels and depth reductions in area 3 were not different from those in area 1.

Hough (1968) and Van Wagner (1972) developed forest floor reduction regressions, based on fuel moisture conditions for burning in southern and northeastern pine stands, respectively. Both regressions underestimated the fuel reduction observed in the study, although

Table 1.-Weather and fire behavior observations during three prescribed burns

\begin{tabular}{ccccccc}
\hline Area & Temperature & $\begin{array}{c}\text { Relative } \\
\text { humidity }\end{array}$ & Windspeed' & $\begin{array}{c}\text { Rate of } \\
\text { spread }\end{array}$ & $\begin{array}{c}\text { Flame } \\
\text { length }\end{array}$ & $\begin{array}{c}\text { Fireline } \\
\text { intensity }\end{array}$ \\
\hline & $\begin{array}{c}\text { degrees } \\
\text { Fahrenheit }\end{array}$ & percent & miles per hour & $\begin{array}{c}\text { feet per } \\
\text { minute }\end{array}$ & feet & $\begin{array}{r}\text { Btu per foot } \\
\text { per second }\end{array}$ \\
& $75-78$ & $33-41$ & $1-4$, upslope & 0.51 & $0.3-0.6$ & $0.3-1.8$ \\
2 & $70-75$ & $45-55$ & $1-3$, upslope & .45 & $.4-.8$ & $.8-3.8$ \\
3 & $68-74$ & $19-28$ & $1-4$, upslope & .54 & $.5-1.0$ & $1.2-5.7$ \\
& & & & & &
\end{tabular}

${ }^{1}$ Measured at 4.5 feet above the ground. 
moisture values of specific layers were not strictly comparable. In northern Arizona, Davis et al. (1968) reported ponderosa pine duff reduction of $33 \%$ and $36 \%$, with $\mathrm{H}$ layer moisture of $18 \%$ and $26 \%$, respectively. These reductions were much less than those found in this study under similar conditions, but original loadings were only $40 \%$ to $70 \%$ of those reported here.

This situation, where lighter original loadings may lead to relatively lower fuel reduction, as suggested by Sweeney and Biswell (1961), was also interpreted from Gaines et al. (1958). In that study, 4-7 tons per acre of ponderosa pine fuels were reduced only $50 \%$, with $9-12 \%$ fuel moistures, and warm, dry, ambient conditions. A more recent study, in ponderosa pine stands of northern Arizona, showed a $63 \%$ forest floor weight reduction, with surface fuels averaging $8-12 \%$ moisture, and the $\mathrm{F}$ and $\mathrm{H}$ layer averaging less than $20 \%$ moisture (Sackett 1980). These moisture conditions were comparable to those in area 2 of this study, which had a $74 \%$ forest floor reduction when open and closed groups were combined. Also, with the $\mathrm{H}$ layer at $28 \%$ moisture content, Sackett (1980) reported a $42 \%$ forest floor reduction, which is less than a $61 \%$ reduction under similar conditions of this study (area 3). Evening and night burning with low air temperatures and higher relative humidities in Sackett's study as opposed to mid-day burning in this study could explain the fuel reduction differences.

Percent reduction of larger fuel ( $>3$ inches) is shown in table 4 . High variability prevented valid statistical comparisons.

More of this fuel class was burned in the open groups, and more rotten material was consumed in both groups than sound material. Moisture contents of sampled logs were quite inconsistent, because of their variable physical characteristics and location within the stand, with regard to openings, drip zones, and canopy cover. The sample size of only two was not adequate for this variability. In contrast to consumption of smaller fuels, reduction of rotten, <3-inch fuels in the open groups appeared slightly greater in area 1 . Area 2 sound fuels burned poorly in both open and closed groups, probably because much of them occurred as single logs. In the other areas, more logs were grouped, permitting
Table 4.-Percent weight reduction of $>3$ inch woody fuels $(n=3$ plots per area)

\begin{tabular}{lcrcc}
\hline $\begin{array}{l}\text { Maturity } \\
\text { group }\end{array}$ & Area & Sound & Rotten & Total \\
\hline \multirow{2}{*}{ Open } & 1 & 64.8 & 74.7 & 72.6 \\
& 2 & 20.9 & 56.5 & 40.1 \\
& 3 & 67.2 & 54.5 & 57.6 \\
Closed & 1 & 38.5 & 23.8 & 31.1 \\
& 2 & 6.5 & 47.7 & 29.2 \\
& 3 & 39.9 & 43.2 & 42.6 \\
\hline
\end{tabular}

heat transfer between them and more complete burning (Albini 1976). In addition, 7 hours after ignition, a light rain dampened the smoldering fires on area 2 , further reducing total consumption. In general, most large fuels were at least charred, reducing their ignitability.

Sackett (1980) also found inconsistent reduction of $<3$-inch fuels. Under fairly dry conditions, $99 \%$ of the rotten material burned, but only $14 \%$ of the sound material was lost. Under wetter conditions, relatively equal percentages ( $41 \%$ and $47 \%$ ) of rotten and sound fuels were consumed.

The effects of the three burns on the stand are illustrated in table 5 . The smallest trees were killed most easily, thereby increasing the average stand diameter. Greatest tree mortalities were associated with areas of greatest fuel reduction. In the open groups, basal areas decreased only slightly, because the larger trees were not affected by the fires. Basal areas were significantly changed in the closed groups because of the high mortality rate.

The ladder fuels, such as low-crowned seedlings and saplings, can permit an intense ground fire to move into the overstory crowns. The following percentages of seedlings and saplings, respectively, were killed: area 1 , $57 \%$ and $16 \%$; area $2,96 \%$ and $54 \%$; area $3,84 \%$ and $43 \%$. Even where trees were not killed, the previously low

Table 3.-Percent of forest floor weight and depth reduction with standard deviations $(n=3$ plots per area)

\begin{tabular}{|c|c|c|c|c|c|}
\hline $\begin{array}{l}\text { Maturity } \\
\text { group }\end{array}$ & Area & $\begin{array}{l}\text { Total } \\
\text { fuels }\end{array}$ & $\begin{array}{c}\text { Forest } \\
\text { floor } \leqslant 1 \text { inch }\end{array}$ & $\begin{array}{l}\text { Needles } \\
\text { or humus }\end{array}$ & $\begin{array}{l}\text { Forest } \\
\text { floor depth }\end{array}$ \\
\hline Open & $\begin{array}{l}1 \\
2 \\
3\end{array}$ & $\begin{array}{l}46.2 \pm 16.7 a^{1} \\
74.8 \pm 6.5 b \\
60.3 \pm 9.9 a, b\end{array}$ & $\begin{array}{l}39.9 \pm 12.9 \mathrm{a} \\
78.7 \pm 5.2 \mathrm{~b} \\
62.3 \pm 11.2 \mathrm{~b}\end{array}$ & $\begin{array}{l}35.8 \pm 13.6 a \\
77.0 \pm 8.8 b \\
62.1 \pm 12.2 b\end{array}$ & $\begin{array}{l}52.8 \pm 6.5 a \\
80.5 \pm 5.7 b \\
64.5 \pm 6.8 a\end{array}$ \\
\hline Closed & $\begin{array}{l}1 \\
2 \\
3\end{array}$ & $\begin{array}{l}34.1 \pm 10.5 a \\
53.9+9.8 b \\
54.2 \pm 8.4 b\end{array}$ & $\begin{array}{l}36.0 \pm 9.0 a \\
67.4 \pm 4.5 b \\
58.7 \pm 5.9 b\end{array}$ & $\begin{array}{l}33.3 \pm 12.8 a \\
67.4 \pm 3.6 b \\
55.6 \pm 9.8 b\end{array}$ & $\begin{array}{l}43.1 \pm 6.0 a \\
74.6 \pm 9.4 b \\
62.1 \pm 9.1 b\end{array}$ \\
\hline
\end{tabular}

${ }^{1}$ Means in columns followed by different letters are significantly different, $P=0.05$. 
crowns were raised when scorched foliage fell. The crowns in the closed groups were approximately 5 feet above the forest floor before burning and were raised to about 8 feet in area 1 and 14 feet in areas 2 and 3 . The removal of these aerial fuels, along with the ground fuels, reduced the crowning potential, just as Kilgore and Sando (1975) reported. However, the area should be reburned to remove the fire-created litter.

In general, the results of this study compare favorably to successful prescribed burning described by Weaver (1952) and Biswell et al. (1973). Fuel reduction was effective and the fires remained completely controllable. That burning, however, was conducted during cool, dry, fall conditions which occur infrequently in the Southwest.

\section{Preliminary Burning Prescriptions}

The L layer moisture contents during the three burns were similar within maturity groups, with the possible exception of area 1 of the closed groups (table 2). They all carried fire at about the same rate of spread. Differences in forest floor fuel consumption were related closely to $\mathrm{H}$ layer moisture differences. Therefore, by holding weather and L layer moisture to narrow ranges, a very preliminary prescription for fuel reduction was developed (table 6).

The air temperature and windspeed ranges have been expanded downwards and upwards, respectively, beyond those conditions encountered during these burns. These changes, based on experience, will broaden the prescription limits while influencing fuel reduction and fire behavior only slightly. The $\mathrm{L}$ layer moisture ranges could be expanded somewhat, especially in the open groups, but these would coincide with unfavorable changes in the closed groups. For example, if the open L layer had $9 \%$ or $10 \%$ moisture, the corresponding moisture in closed groups would be approaching the moisture of extinction for backing fires $\left(\mathbf{1 2 - 1 4 \% )}{ }^{3}\right.$

Control problems were minimal during these summer burns. In area 1 , with moist $F$ and $H$ layer fuels, no problems were encountered as the low intensity fire backed slowly. Even with the drier fuel conditions in area 2, the
Table 6. - Preliminary burning prescriptions with expected fuel reductions (percent) for ponderosa pine stands in the Santa Catalina Mountains ${ }^{1}$

\begin{tabular}{lccc}
\hline $\begin{array}{l}\text { Maturity } \\
\text { group }\end{array}$ & $\begin{array}{c}\text { L layer } \\
\text { moisture }\end{array}$ & $\begin{array}{c}\text { H layer } \\
\text { moisture }\end{array}$ & $\begin{array}{c}\text { Forest floor } \\
\text { reduction }\end{array}$ \\
\hline Open & $5-7$ & $15-25$ & $75-85$ \\
& $5-7$ & $30-40$ & $55-65$ \\
& $5-7$ & $75-90$ & $30-40$ \\
Closed & $6-9$ & $25-35$ & $65-75$ \\
& $6-9$ & $50-60$ & $50-60$ \\
& $6-9$ & $70-85$ & $30-40$ \\
\hline
\end{tabular}

'Weather conditions applicable for downslope, backing fires only. Air temperatures: $55-75^{\circ} \mathrm{F}$. Relative humidities: $25-50 \%$. Wind at 4.5 feet: upslope, $1-5$ miles per hour.

backing fire was easily managed. Short strip head fires, used to straighten out fire fronts, burned more intensely and increased scorch heights. Heavy fuels ignited rapidly and burned fiercely for some time, causing individual or group crowning or severe scorching directly above. This normally occurred in dense sapling groups, where thinning may be beneficial. Surface fuels ignited more rapidly in area 3 because of low moisture contents. Again, individual or group crowning occurred infrequently, but created no control problems.

Fire danger and fuel reduction success of these prescriptions differ somewhat from those predicted by Allen et al. (1968). Figure 3 shows tentative prescription limits for burning low volume fuels in Southwest forest understory. Conditions encountered during the burning of areas 1,2 , and 3 are marked.

The prediction guide (Allen et al. 1968) shows greater fire danger when area 1 was burned than area 2. Actually, drier fuels in area 2 caused higher intensities. Also, according to Allen et al. (1968), area 3 was burned in the fire-danger-too-high-for-control range, but no problems were encountered with the slow-moving backing fires. These comparisons suggest that relative humidity and fuel stick moisture alone are not sufficient prescription parameters. This prediction guide is being reevaluated.

Table 5.-Changes in stand characteristics from three prescribed burns

\begin{tabular}{|c|c|c|c|c|c|c|c|c|c|c|}
\hline \multirow{2}{*}{$\begin{array}{l}\text { Maturity } \\
\text { group }\end{array}$} & \multirow[b]{2}{*}{ Area } & \multicolumn{3}{|c|}{ Average d.b.h. } & \multicolumn{3}{|c|}{ Trees per acre } & \multicolumn{3}{|c|}{ Basal area per acre } \\
\hline & & Before & After & Increase & Before & After & Decrease & Before & After & Decrease \\
\hline & & in & $s \ldots$ & percent & & & percent & square fe & ber acre & percent \\
\hline Open & $\begin{array}{l}1 \\
2 \\
3\end{array}$ & $\begin{array}{l}3.2 \\
5.6 \\
6.7\end{array}$ & $\begin{array}{r}3.9 \\
9.9 \\
11.7\end{array}$ & $\begin{array}{l}21.9 \\
76.8 \\
74.6\end{array}$ & $\begin{array}{l}820 \\
490 \\
500\end{array}$ & $\begin{array}{l}595 \\
195 \\
325\end{array}$ & $\begin{array}{l}27.4 \\
60,2 \\
35.0\end{array}$ & $\begin{array}{l}163 \\
191 \\
269\end{array}$ & $\begin{array}{l}157 \\
187 \\
267\end{array}$ & $\begin{array}{l}3.6 \\
2.1 \\
0.7\end{array}$ \\
\hline Closed & $\begin{array}{l}1 \\
2 \\
3\end{array}$ & $\begin{array}{l}2.4 \\
2.4 \\
2.6\end{array}$ & $\begin{array}{l}2.7 \\
3.6 \\
3.3\end{array}$ & $\begin{array}{l}12.5 \\
50.0 \\
26.9\end{array}$ & $\begin{array}{l}3,230 \\
3,885 \\
3,420\end{array}$ & $\begin{array}{l}2,460 \\
1,750 \\
1,910\end{array}$ & $\begin{array}{l}23.8 \\
55.0 \\
44.2\end{array}$ & $\begin{array}{l}179 \\
191 \\
187\end{array}$ & $\begin{array}{l}171 \\
143 \\
156\end{array}$ & $\begin{array}{r}4.5 \\
25.3 \\
16.6\end{array}$ \\
\hline
\end{tabular}




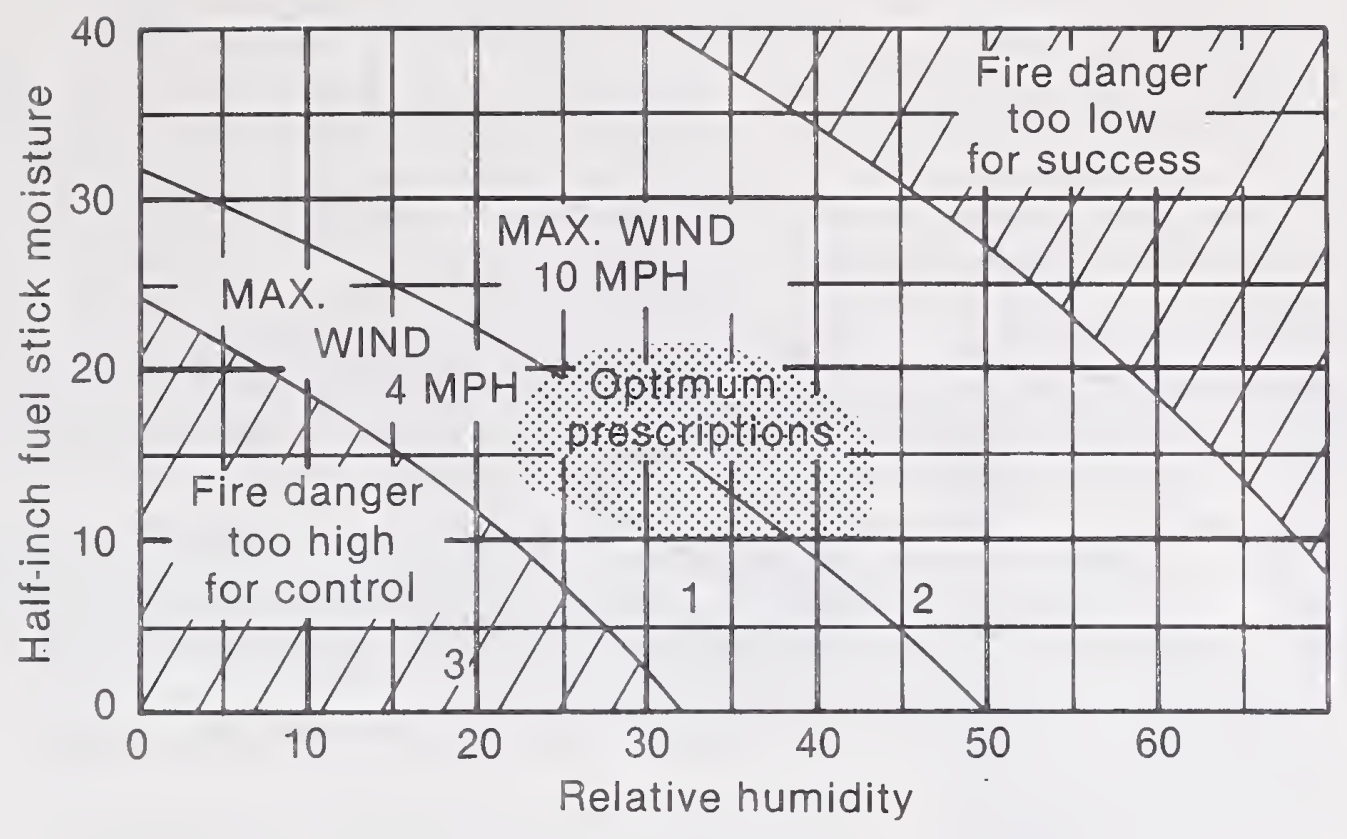

Figure 3.-Prediction guide for Southwest forest understory burning (Allen et al. 1968). Conditions during the three burns reported here are marked.

It should be emphasized that the execution of safe, effective prescribed burns under the stand, fuel, and weather conditions of this study depends on patient con. trol of downslope backing fires. Much burning time will be required for initial fuel reductions with these creeping, deliberate fires, but strict adherence to this rule is necessary to maintain control.

\section{Literature Cited}

Albini, Frank A. 1976. Computer based models of wildland fires behavior: A user's manual. 68 p. U.S. Department of Agriculture, Forest Service. Intermountain Forest and Range Experiment Station, Ogden, Utah.

Allen, Myron H., R. W. Berry, Dexter Gill, G. Lloyd Hayes, Paul S. Truesdell, Malcolm Zwolinski, and John M. Pierovich. 1968. Guide to prescribed fire in the Southwest. 58 p. Southwest Interagency Fire Council, Tucson, Ariz.

Biswell, Harold H., Harry R. Kallander, Roy Komarek, Richard J. Vogel, and Harold Weaver. 1973. Ponderosa fire management. Miscellaneous Publication 2. 49 p. Tall Timbers Research Station, Tallahassee, Fla.

Brown, James K. 1974. Handbook for inventorying downed woody fuels. USDA Forest Service General Technical Report INT-16, 24 p. Intermountain Forest and Range Experiment Station, Ogden, Utah.

Byram, G. M. 1959. Combustion of forest fuels. p. 90. In Forest Fire: Control and use. Kenneth P. Davis, editor. McGraw-Hill Book Co., New York, N.Y.
Davis, James R., Peter F. Ffolliott, and Warren P. Clary. 1968. A fire prescription for consuming ponderosa pine duff. USDA Forest Service Research Note RM-115, 4 p. Rocky Mountain Forest and Range Experiment Station, Fort Collins, Colo.

Gaines, Edward M., Harry R. Kallander, and Joe A. Wagner. 1958. Controlled burning in southwestern ponderosa pine: Results from the Blue Mountain plots, Fort Apache Indian Reservation. Journal of Forestry 56:323-327.

Hough, W. A. 1968. Fuel consumption and fire behavior of hazard reduction burns. USDA Forest Service Research Paper SE-36, 7 p. Southeastern Forest Experiment Station, Asheville, N.C.

Kilgore, Bruce M., and Rodney W. Sando. 1975. Crownfire potential in a sequoia forest after prescribed burning. Forest Science 21(1):83-87.

Sackett, Stephen S. 1979. Natural fuel loadings in ponderosa pine and mixed conifer forests of the southwest. USDA Forest Service Research Paper RM-213, 10 p. Rocky Mountain Forest and Range Experiment Station, Fort Collins, Colo.

Sackett, Stephen S. 1980. Reducing natural ponderosa pine fuels using prescribed fire: Two case studies. USDA Forest Service Research Note RM-392, 6 p. Rocky Mountain Forest and Range Experiment Station, Fort Collins, Colo.

Sweeney, James R., and Harold H. Biswell. 1961. Quantitative studies of the removal of litter and duff by fire under controlled conditions. Ecology 42(3):572-575.

Van Wagner, C. E. 1972. Duff consumption by fire in eastern pine stands. Canadian Journal of Forest Research 2:34-39.

Weaver, Harold. 1952. A preliminary report on prescribed burning in virgin ponderosa pine. Journal of Forestry 50:662-667. 


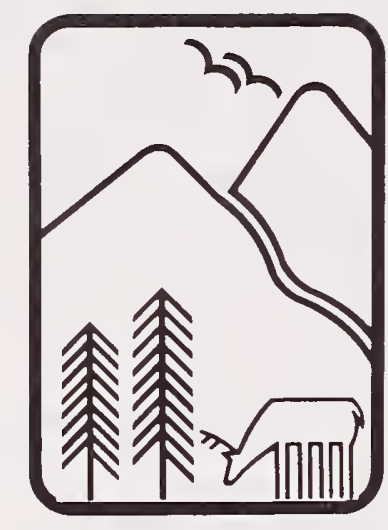

Rocky
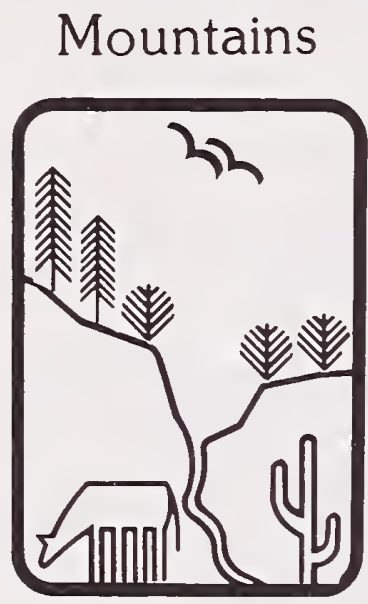

Southwest

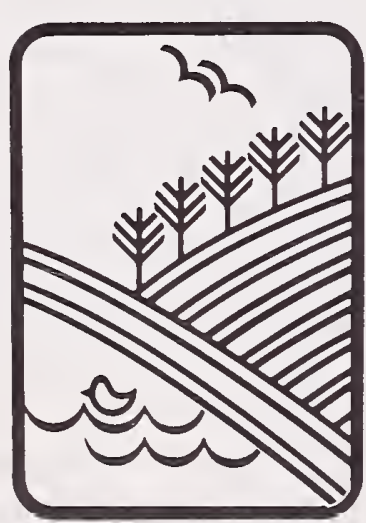

Great Plains
U.S. Department of Agriculture

Forest Service

\section{Rocky Mountain Forest and Range Experiment Station}

The Rocky Mountain Station is one of eight regional experiment stations, plus the Forest Products Laboratory and the Washington Office Staff, that make up the Forest Service research organization.

\section{RESEARCH FOCUS}

Research programs at the Rocky Mountain Station are coordinated with area universities and with other institutions. Many studies are conducted on a cooperative basis to accelerate solutions to problems involving range, water, wildlife and fish habitat, human and community development, timber, recreation, protection, and multiresource evaluation.

\section{RESEARCH LOCATIONS}

Research Work Units of the Rocky Mountain Station are operated in cooperation with universities in the following cities:

Albuquerque, New Mexico

Bottineau, North Dakota

Flagstaff, Arizona

Fort Collins, Colorado*

Laramie, Wyoming

Lincoln, Nebraska

Lubbock, Texas

Rapid City, South Dakota

Tempe, Arizona

*Station Headquarters: 240 W. Prospect St., Fort Collins, CO 80526 